Témoigner Témoigner. Entre histoire et mémoire

Getuigen Revue pluridisciplinaire de la Fondation Auschwitz

122 | 2016

Révisionisme et négationisme

\title{
Continual justice in Argentina: Four wraiths of military rule
}

David M. K. Sheinin

\section{OpenEdition}

1 Journals

\section{Electronic version}

URL: https://journals.openedition.org/temoigner/4664

DOI: 10.4000/temoigner.4664

ISSN: 2506-6390

Publisher:

Éditions du Centre d'études et de documentation Mémoire d'Auschwitz, Éditions Kimé

\section{Printed version}

Date of publication: 2 May 2016

Number of pages: 152-161

ISSN: 2031-4183

\section{Electronic reference}

David M. K. Sheinin, "Continual justice in Argentina: Four wraiths of military rule", Témoigner. Entre histoire et mémoire [Online], 122 | 2016, Online since 30 September 2021, connection on 03 February 2022. URL: http://journals.openedition.org/temoigner/4664 ; DOI: https://doi.org/10.4000/temoigner. 4664 


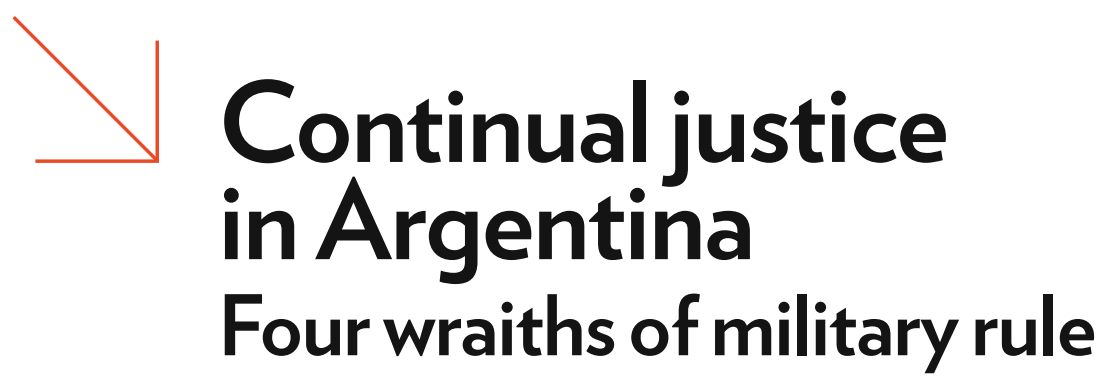

$\rightarrow$ David M. K. Sheinin, Trent University

n Argentina, transitional justice since 1980 is marked by the changeover from brutal dictatorship to nascent democracy where the latter restored judicial order in part by punishing perpetrators of violence. Transitional justice, though, can only be as effective as its capacity to right past wrongs legally, politically, philosophically, and morally. Over the past thirty-five years, the Argentine case is mixed. Dozens of torturers and killers from the last dictatorship (1976-1983) have been prosecuted. At the same time, many have not been brought to justice. Prosecutions are ongoing. The number of those responsible for the killings likely to escape a judicial reckoning will be enormous, as a percentage of those responsible for dictatorship violence and in comparison to some other countries. Transitional justice itself has been fiercely politicized, particularly over the past twelve years during the presidential administrations of Néstor Kirchner (2003-2007) and Cristina Fernández de Kirchner (2007-2015). Many Argentines lauded the accelerated pace of convictions of human rights abusers. Others decried the prosecutorial disinterest in killings carried out by the revolutionary left during the 1970s.

How transitional, though, is transitional justice? Four legal cases underline that continual, not transitional justice has often been a hallmark of post-dictatorship democratic rule since 1983. Successive democratic governments have found it politically expedient, practical, and legally defensible not only to avoid dismantling dictatorship-era law, but to apply and reinforce it in a range of settings.

\section{JACOBO ISAAC GROSSMAN}

In July 1976, soldiers kidnapped Jacobo Isaac Grossman. The military government accused him of extortion, kidnapping, and weapons possession. Sentenced 
by a military court to thirty-nine years in prison, both the dictatorship and the post-dictatorship democratic government maintained that Grossman had been an operative of the Montoneros, a Peronist revolutionary group, and of the Israeli secret service.

After the fall of the dictatorship, human rights and other organizations petitioned for Grossman's release. In refusing to vacate the convictions, despite a range of legal abuses in the dictatorship's prosecution of his case, the post-1983 democratic government drew on its conviction that Grossman had almost certainly been a Montonero. The post-dictatorship government also based its decision to keep Grossman incarcerated on tainted dictatorship intelligence that had identified him as a

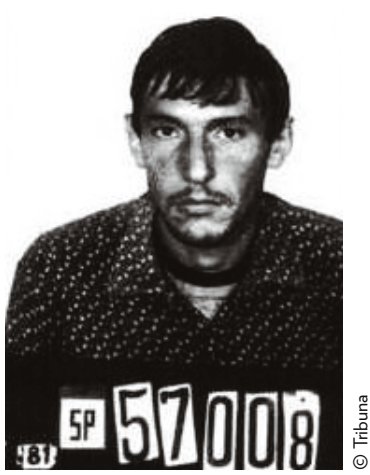

_Jacobo Isaac Grossman, 1976 terrorist. As a matter of law, whether or not he had been a Montonero, the military case against Grossman had been built on an evidentiary house of cards. In one of many examples of the septic evidence base, court documents showed that while Argentine authorities had kidnapped Grossman on 6 July 1976, one of the crimes for which he was incarcerated had been committed on 8 July, two days after his abduction. In failing to vacate Grossman's sentences, the democratic government of the 1980s contravened its own post-dictatorship legislation that had specifically identified for abrogation sentences for victims wrongfully arrested and convicted before 1983. In Grossman's case, convinced that he had been a left-wing terrorist, the democratic government made a pact with the devil by holding him in prison on the basis of a shoddy military government case for having placed him there.

\section{GUILLERMO SUÁREZ MASON}

In 1987-1988, in another case where dictatorship law persisted after the fall of military rule, the Argentine government sought the extradition of Guillermo Suárez Mason from the United States. In 1976 Suárez Mason became commander of the First Army Corps. As such, after the coup d'état he oversaw a number of illegal torture and detention centers as well as Army Intelligence Battalion 601, a unit notorious for illicit killings, extortions, and kidnappings. With the fall of the generals, Suárez Mason escaped to the United States where he was detained at the request of Argentine authorities.

In drafting and executing its extradition strategy in California court, as in the case of Grossman, Argentine authorities opted not to challenge a range of military era decrees and legal positions that had won condemnations from Amnesty International and other rights groups. These included the establishment of War Councils to hold quick trials, the death penalty for those causing severe injury to soldiers 
or police, and the death penalty by firing squad within 48 hours of sentencing. In the extradition of Suárez Mason, there was never a need to turn back the clock on these and other sinister hallmarks of military justice. The Argentine government focused on demonstrating that Suárez Mason's roles in tortures and executions were illegal by the legal norms of the dictatorship itself. As in the Grossman case, by leaving much of dictatorship law intact and invoking it in multiple cases, the post-dictatorship democratic government affirmed that body of law with lasting consequences for Argentina.

In the Grossman case, the damage in affirming dictatorship legal structures was done in the denial of the plaintiff's legal and civil rights under democratic rule. In the Suárez Mason extradition, a different set of parameters was in play. In successfully winning Suárez Mason's extradition, the Argentine government took an unusual and in the end, high-risk approach in upholding the legitimacy of military rule and its legal authority. In 1987-1988, before a US federal court, Argentina confirmed the justice of pre-dictatorship decrees that transferred authority to the military of police measures ostensibly needed to destroy guerrilla operations. The Argentine extradition legal team conceded the 1975 militarization of civil society in the creation of four military zones. One zone would come under the brutal supervision of Suárez Mason who would command all aspects of the hunt for left wing terrorists, real and imagined, as well as police, military, gendarmerie, and penitentiary service operations in his sector. Military authorities, according to Argentine government lawyers in 1987-1988, had had the legal right under dictatorship to detain those under suspicion without charge.

Why would a democratic government make the case for the authority of the 1976-1983 dictatorship to militarize Argentine society, in forms anathema to the international human rights community? To establish a basis for the extradition, Argentine authorities felt their most effective case could be made in how Suárez Mason had veered from what the military had established as "legitimate" in militarizing society. To do so, lawyers for the Argentine government first set the parameters for what was legal under the dictatorship, then showed how Suárez Mason had taken an alternate course the dictatorship had always denied - the maintenance of clandestine detention centres, the killings, and the torture. The Argentine government would show successfully, in the end, that during his tenure as commander of the First Army Corps through February 1979, Suárez Mason administered twenty-four torture and killing centres including Automotores Orletti, Club Atlético, and El Olimpo (from which he derived his nickname, the Butcher of Olimpo). He had been responsible for the approval of a plan to eliminate leftist terrorism. And he had been responsible for human rights abuses as First Corps commander in his personal attention to and supervision of torture sites, all in contravention of the terms of the militarized state the armed forces had themselves established before and after the 1976 coup d'état. 
The story of JoséSiderman, an Argentine hotelier from Tucumán province begins on the night of the 1976 coup d'état that brought the Argentine military power. Ten armed men in masks entered Siderman's home. They kidnapped then tortured him for a week. The story ends more than thirty years later when the Argentine government settled a Siderman family claim in US federal court stemming from the illicit kidnapping, the torture, and the confiscation of his property. Argentina paid the family US\$6 million, all of which went toward establishing an endowed professorship in human rights at the Southwestern Law School in the United States.

All's well that ends well, it might seem on first glance-Argentine transitional justice complemented by the not insignificant role of a US court in finding some justice for a victim of state terror. On closer examination, though, the case is not one of transitional but of continual justice. Rather than break with dictatorship legal norms and precedents, to avoid having to pay the Siderman family, democratic governments in Argentina in the 1980s and 1990s adopted the fraudulent positions of the military government toward Siderman. Moreover, through the mid-1990s, to sidestep that even had he been a terrorist he should not have been subject to illicit detention and torture, democratic governments relied on a legal case fabricated against Siderman by the military regime in the late 1970s to try to block any payout to the Siderman family in US federal court.

The 1975 division of the country into four military zones with new policing and security powers in civil society underlines the continuities between pre-dictatorship and post-dictatorship Argentina. That sinister step toward a militarized society was amplified immediately after the 24 March 1976 coup d'état when the dictatorship named a military governor for each Argentine province. The newly named governor of Tucumán, General Antonio Domingo Bussi, governed with no federal oversight treating the province as a feudal fiefdom.

On the night of the coup d'état, the ten masked men who burst into Siderman's home removed him, then threw him onto the floor of a car where, on the trip to a clandestine detention center, he was repeatedly kicked and threatened with death. His captors tortured him for seven days with an electric prod and in other ways, while calling out "Jew Bastard" and "Shitty Jew" among a range of anti-Semitic insults. At the time, Siderman was the principal owner of Inmobiliaria del Nor-Oeste, SA (INOSA) which was in the process of building the largest hotel in the north of Argentina, the Hotel Gran Corona in the city of Tucumán. His illicit detention in 1976 was not his first. In 1974, the Montonero guerrilla group had kidnapped Siderman and had held him for three weeks until a substantial ransom had been paid.

Like many other aspects of the new authoritarian state, including the construction in advance of clandestine detention centers complete with architectural touches 
such as drains for blood in rooms designated for torture, Siderman was among many Argentines targeted in advance by incoming military rulers for illegal property seizure. Because the earlier Montonero kidnapping and Siderman's ransom payment had been well publicized, the military knew he likely had wealth that might be stolen. In addition to his having been snatched from his home the same day as the coup d'état, no sooner had the coup been declared, the residential sector of the city where Siderman lived was declared an emergency military zone and the streets cleared of non-military personnel. Though blindfolded, during his kidnapping Siderman heard his masked captors issuing and responding to military orders. During his internment, Siderman's torturers told him he had best leave the country. In addition, that night military operatives captured some 300 other tucumanos for the purpose of extortion and theft.

On his release from detention, Siderman fled the country. Shortly after, the military government issued an ex post facto extradition order in response to a federal court's conclusion that Siderman had committed fraud. Bussi and his allies in Tucumán set in motion a scheme to win control of Siderman's property. They falsified provincial property registries to show Siderman's ownership of only 127 acres of the 127,000 he held in the province. They altered public records to take control of INOSA, while imprisoning then assassinating the accountant Siderman had left in charge of the company on leaving the country.

In 1982, the Siderman family filed a complaint in US federal court asserting eighteen causes of action for torture, harassment, and the illicit expropriation of their property. It was not until 1996, though, that Siderman won the out-of-court settlement from the Argentine government. As late as that year, despite overwhelming evidence to the contrary, the Argentine government held that the Siderman family had legally sold the hotel in question to Miguel Naief Mejail in 1977. That falsified record of a sale was upheld in 1983 by a civil court in Tucumán, with Argentina still under military rule and the civil court system cowed. The Argentine government, still under dictatorial rule, maintained that false position when Siderman initiated his complaint in the United States in 1982. It held that stand through the mid-1990s in the hope of avoiding a payout to Siderman.

Throughout the 1980s and early 1990s, in its efforts to avoid a financial settlement with Siderman, the democratic Argentine government rejected evidence of the military governor's authorship of the 1976 kidnapping and torture, and disputed Siderman's claim that Bussi had swindled him out of his holdings. Through the 1990s, it continued to argue that the Siderman family had sold its interests in INOSA and the Hotel Gran Corona on 13 April 1977.

In addition, Argentina advanced the position in court that even had the military government in Tucumán been responsible for the kidnapping, Argentina's responsi- 
bility for damages were limited to medical expenses, "moral damage", and "psychological damage" - a sum much smaller than the millions sought by the Sidermans.

Federal legislation passed in Argentina after 1983 brought into question decisions by civilian courts during the dictatorship on the assumption that they could not have functioned free of the threat of military intervention and violence. Despite this, in the Siderman case, through the mid-1990s the Argentine government cited dictatorship era decisions by the First Federal Court of Tucumán rejecting claims for damages made by the Sidermans at the time. Moreover, rejecting arguments made by the Sidermans and human rights groups that Bussi had conspired to seize Siderman's property for personal gain, Argentina argued the military government's position in US federal court: The properties had been confiscated as a matter of an ambiguously outlined "public interest".

Democratic Argentina defended Siderman's ex postfacto extradition by military authorities, rehearsing the dictatorship's claim that the extradition had come in response to his having committed fraud (determined by a civil court in Tucumán under military rule). In perhaps the most remarkable example of continual justice in Argentina, the Argentine government slammed Siderman for having "fraudulently" obtained a forged police certificate of good conduct and a passport. That is to say, fearing for his life and to escape dictatorship in the aftermath of his torture and detention, Siderman had paid for false documents to leave Argentina. Both military and later, democratic governments held this against him.

The government finally settled with the Siderman family only after it became clear that its potential financial losses in prosecuting the case might outweigh a settlement. Bruno Ristau, the Argentine government's chief counsel in the United States, calculated that by 1996, Argentina had spent as much as US\$700,00 on the case and estimated the need for an additional US\$200,000 before the case could even go back to court. Moreover, Argentina's key witness in the case was refusing to testify. Sonia Mejial, the late Miguel Naief Mejail's daughter and the owner of what had once been the Sidermans' hotel, refused to testify on the supposed sale of the hotel by Siderman until Argentine authorities paid her an unspecified settlement amount she had reached with the Argentine government for her own family's loss of property to military seizure during the dictatorship.

\section{OSVALDO ANTONIO LÓPEZ}

In 1985, Osvaldo Antonio López, a former Argentine Air Force corporal argued before the Inter-American Human Rights Commission that democratic Argentina had violated his human rights. Two years later, the Commission declared López a political prisoner. As in the Siderman and Grossman cases, the Argentine government had countered López's claims by depending on legal arguments structured by 


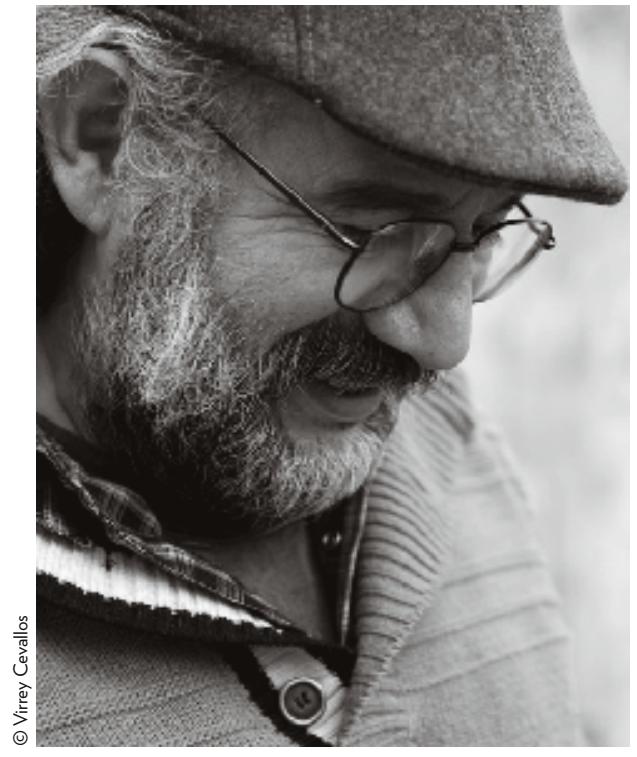

_ Osvaldo Antonio López, 2013 the preceding, military government, starting with a 1976 ruling by the Appeals Court of La Plata.

On 29 April 1976, Air Force officers claimed they had found photographs and diagrams indicating the locations of fighter jets hidden in the gas tanks of six Mirage III E aircraft at an Air Force base in Morón. The find suggested to authorities a leftist subversive plot. López had been on the base when the documents were uncovered. He stated his innocence from the outset and would demonstrate at trial that he had never been left alone during his shift, so could not have planted the material in question. The trial also showed that the night before the find, a base door had been left open. There had been nobody at the security station at that entry point. The case against López was weak and the court dismissed it.

In July 1977, masked gunmen kidnapped López, a leftist political militant but not a terrorist. As was Siderman, López was transported blindfolded to an illicit detention centre where he was held for a week. Unlike Siderman, López escaped detention, issued a formal denunciation before a court in the province of Córdoba then went into hiding. Unidentified men in military gear searched the homes of his family. López turned himself in to face desertion charges on learning that his relatives had been threatened by the military. During a torture session, he confessed to having set explosives in the jet where the photos had been found. He claimed to have been in contact with the leftist guerrilla group, Ejército Revolucionario del Pueblo (ERP) and that he had passed on to ERP members classified documents. This was inspired, he told his torturers, by his love for Gladis Aoad, a woman with supposed links to the ERP.

On the basis of this testimony, the military charged López with treason. Soldiers who had lived with López, his neighbourhood companions, and others gave depositions that they had no information that López was involved in politics. No other evidence corroborated López's admission of guilt. Moreover, the explosives López supposedly placed in the jet had not been found in the initial discovery of documents and photographs. López was convicted and sentenced to twenty-four years in prison on charges of illicit association and the revelation of secrets concerning national defense.

López based his post-dictatorship sentence appeal on the military having illegally ignored his earlier appeals and his right to a public defender. In 1985, before the Inter-American Human Rights Commission he cited Argentine Law 23,049, passed after the fall of the dictatorship, limiting the competence of military tribunals to infractions against the military itself. Though an Air Force corporal at the time of his detention, López argued that the crimes of which he had been accused 
and the circumstances of his prosecution were equivalent to those faced by civilians during military rule. As a result, he claimed, Law 23,049 applied to his case. The democratic Argentine government countered López by defending the legitimacy of legal proceedings under the dictatorship. Privately though, the Argentine Foreign Ministry advised the office of the President that Argentina's questionable legal position in this high-profile case would strain the international credibility of Argentine democracy, which continued to incarcerate a prisoner convicted under by the dictatorship in sham trials.

\section{THE DAMAGE}

Argentine democracy pioneered and championed hundreds of legal and administrative changes after 1983 to reverse the damage of authoritarian rule. These included the constitution of the first truth and reconciliation commission anywhere. Why, then, were democratic governments in the 1980s and 1990s repeatedly willing to invoke dictatorship era decrees, court decisions, and procedures in a broad range of proceedings, if not in secret then often outside public scrutiny? The answer is perhaps clearest in the Suárez Mason extradition where the decision to uphold dictatorship legal norms was adopted as part of a successful, pragmatic strategy to win the human rights violator's extradition.

But in addition, in cases where there had been accusations of left-wing guerrilla terrorism, the 1980s Argentine government gave both political and legal credence to their military predecessor's approach. In the early stages of democracy's reckoning with dictatorship, the government adopted publicly what became known as the theory of "the two demons". The military dictatorship and left-wing terrorists were jointly held to account for Argentina's descent into political violence and authoritarian rule during the 1970s. Privately, there were those in government who remained suspicious of Grossman, López, and others detained during military rule, believing that the generals had likely been right in accusing them of left-wing violence - and willing to keep them in prison, despite the illicit means of the dictatorship in placing them there.

Democracy faced two additional pressures that account for continual justice. Through the 1980s, Argentines believed the threat of a new military coup possible, if not imminent. The government structured a broad range of its policies so as to avoid prompting the sort of military uprising it faced over Easter in 1987 when, for three days, the country remained on tenterhooks as rogue officers and their units tried to take over the government. More banal, but perhaps more important, despite the many important legislative and policy changes democracy brought about, Argentine leaders found it impossible as a practical matter to dismantle altogether dictatorship legal norms and precedents. They were intermeshed with decrees, legislation, and precedent from even earlier democratic and military governments. Moreover, 


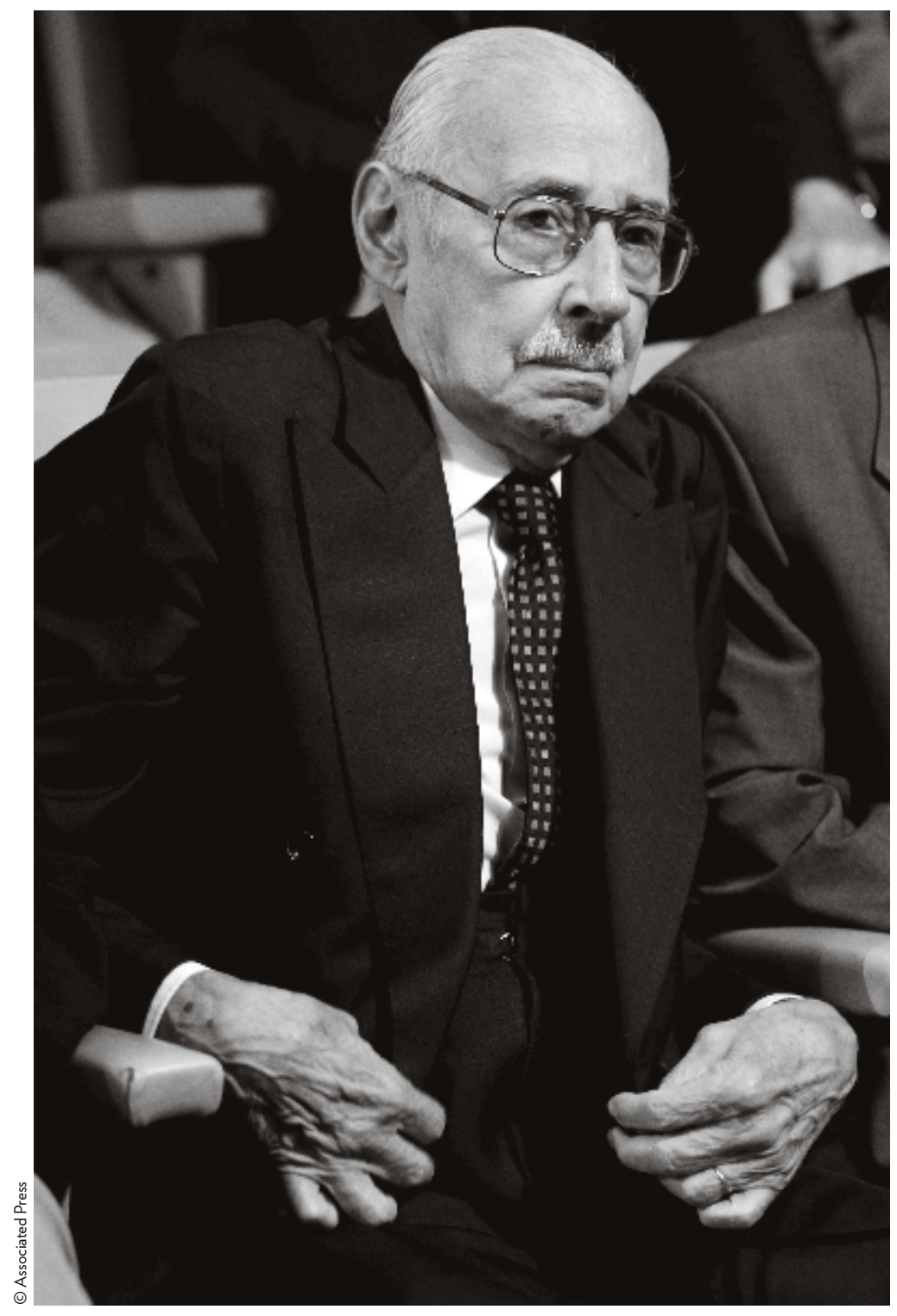

many dictatorship erajudgments in both military and civil courts were uncontroversial decisions on criminal and other matters.

Perhaps the most morally questionable single position adopted by the Argentine government in reference to the dictatorship persisted through the 1980s and as late as 1996. Argentina argued in California court that José Siderman's claims for damages as a result of his illicit detention and torture were unreasonable in part because his torturers were masked. Despite a range of other evidence conceded that military authorities had held Siderman, the Argentine government sought to limit its legal liability by insisting that his captors were "unknown" assailants.

Is there a causal relationship between post-1983 Argentine governments walking a fine line between eradicating remnants of the dictatorship from Argentine society and drawing on and upholding that same dictatorship legal edifice? Is there a long-term price for a democratic government hanging legal interpretations on arcane interpretations that justify dictatorship legalities but at the same time raise doubts on what is morally and legally right (as in the case of Foreign Ministry concerns

_ Jorge Rafael Videla during a 2013 trial over the bad optics of the López file)? Whatever the case, the interminable prosecutions of dictatorship killers and torturers is due in part to the sorts of legal contortions and fine points that the Argentine government exploited in 1996 when it tried to counter Siderman's claim by hiding behind the questionable anonymity of his torturers. 
One case where the legacy of the dictatorship hinged on legal nuance rather than sustained judicial action came in the aftermath of President Carlos Menem's 1990 pardon of those Argentine military leaders convicted in 1985 of dictatorship-related crimes. De facto president Jorge Rafael Videla was sentenced to life in prison on multiple charges relating to torture, kidnapping, and homicide. Freed by the 1990 pardon, the Argentine judiciary found no way to put him behind bars again until 1998 when enterprising prosecutors found a loophole. There was one crime for which Videla and others had not been convicted in 1985 and for which, therefore, they had not received a presidential pardon - the kidnapping of children of those detained. In 1998, Videla was sentenced and imprisoned for that crime.

\section{WORKS CITED}

- Bell, Vikki, The Art of Post-Dictatorship: Ethics and Aesthetics in Transitional Argentina, New York: Routledge, 2014.

- Bohoslavsky, Juan Pablo, ¿Usted también doctor? Complicidad de jueces, fiscales y abogados durante la dictadura, Buenos Aires: Siglo Veintiuno, 2015.

- Crenzel, Emilio, 'Genesis, Uses and Significance of the Nunca Más Report in Argentina', Latin American Perspectives 42, 2015, 20-38.

- Gatti, Gabriel, Surviving Forced Disappearance in Argentina and Uruguay: Identity and Meaning, London: Palgrave Macmillan, 2014.

- Lessa, Francesca, Memory and Transitional Justice in Argentina and Uruguay: Against Impunity, London: Palgrave Macmillan, 2014.

- Sheinin, David M. K., Consent of the Damned: Ordinary Argentineans in the Dirty War, Gainesville: University Press of Florida, 2012. 